\title{
Energy prices and emissions trading: windfall profits from grandfathering?
}

\author{
E. Woerdman $\cdot$ O. Couwenberg $\cdot$ A. Nentjes
}

Published online: 25 March 2009

(C) The Author(s) 2009. This article is published with open access at Springerlink.com

\begin{abstract}
The greenhouse gas emissions trading scheme in the European Union primarily uses grandfathering until 2012, which means that polluters get emission rights free of charge based on their historical emissions. Energy consumers accuse energy producers of making windfall profits by incorporating the market value of those free rights into the energy prices. However, we develop a numerical example to illustrate that the reasoning of the producers is correct. We also explain why this market value is only partly passed on to consumers. We consider various measures and conclude that only auctioning the rights after 2012 nullifies the additional profits.
\end{abstract}

Keywords Emissions trading - Energy prices - Windfall profits ·

Opportunity costs · Grandfathering · Auctioning

JEL Classification D21 $\cdot \mathrm{D} 62 \cdot \mathrm{K} 32 \cdot \mathrm{Q} 48 \cdot \mathrm{Q} 54$

In 2003, the European Union (EU) adopted Directive 2003/87/EC on greenhouse gas emissions trading. This market started in 2005. The Directive requires that governments allocate the emission rights free of charge. This means that polluters do not have to buy their emission rights, or allowances, in an auction. Instead the allowances are allocated free of charge to polluters, based on their historical emissions. This way of allocating is called grandfathering. Article 10 of the Directive specifies that for the period 2005-2007 at least $95 \%$ of the allowances should be handed out for free and at least $90 \%$ for the current period 2008-2012.

E. Woerdman $(\bowtie) \cdot$ O. Couwenberg $\cdot$ A. Nentjes

Faculty of Law, Department of Law and Economics, University of Groningen, P.O. Box 716, 9700 AS Groningen, The Netherlands

e-mail: e.woerdman@rug.nl 
The energy industry is the largest sector in the scheme, responsible for more than half of total covered emissions (Christiansen et al. 2005).

In spite of the increased acceptance of emissions trading, some of its institutional elements are still controversial, especially the allocation mechanism and the setting of the Member States' emission caps (e.g. Neuhoff et al. 2006). The decision to grandfather the allowances lead to a 'significant outcry about windfall profits' (Ellerman and Buchner 2007: 73). Econometric research has confirmed that energy producers partly pass on the market value of freely obtained $\mathrm{CO}_{2}$ emission rights to energy consumers (e.g. Point Carbon 2008; Smale et al. 2006; Frontier Economics 2006; Sijm et al. 2005). This was and still is a "hot item" in the political and public debate: newspapers and policy magazines all over Europe have written about the windfall profits those companies would make. Also some economists have expressed their concerns about those particular gains (e.g. Jepma 2006). Moreover, with respect to defining the national caps, EU Member States have been generous in allocating the emission rights, at least for the period 2005-2007 (e.g. Ellerman and Buchner 2006; Böhringer et al. 2005). As a consequence, the call for measures against the windfall profits from emissions trading became louder and louder (e.g. Grubb and Neuhoff 2006; Whitehead 2005).

For the time being, this has resulted in a more or less consensual approach within Member States to allocate relatively stringent emission ceilings to the power sector for the period 2008-2012. For the period after 2012, the European Commission proposed to auction off all allowances to the electricity industry (COM 2008). The European Council agreed, but also made an exemption for existing power generators in primarily Eastern European Member States, where the auctioning rate must be at least $30 \%$ in 2013 and $100 \%$ in 2020 (EC 2008: 3, 14).

With the introduction of a market for emission rights, $\mathrm{CO}_{2}$ would be priced, making it more expensive to pollute. However, the research reports and newspaper articles suggest that polluters now make additional profits by incorporating these rights as "opportunity costs" in the calculation of the cost price. At first glance, the indignation of consumers seems right, because the producers appear to receive and use those rights for free. Free emission rights do not seem to show up as direct costs in the cost price. Yet we argue that passing on the market value of these rights as costs to the consumers is economically correct and that various implemented and contemplated measures against windfall profits will not make an end to those gains. Contrary to some complex reports on this matter, and the sometimes confusing newspaper stories, we will make our point by developing a simple but relevant numerical example, based on micro-economic theory.

We use this example to answer the following central question: should energy consumers pay for the allowances that energy producers obtained for free? When elaborating upon and answering this question, we primarily focus on the supply side of markets. Of course, energy prices are determined by supply and demand, but we analyze the value and costs of emission rights as one of the production factors that determine supply curves, because this aspect of the market has recently created so much controversy. Our article can be seen as part of the emerging literature on the interactions between climate policy and energy policy (e.g. Bonacina and Gullì 2007; Sijm et al. 2006). 
The article is structured as follows. In Sect. 1, we explain the economic impact of the opportunity costs of grandfathered allowances on energy prices, assuming pricetaking behaviour. In Sect. 2, we take a look at the limits of passing on opportunity costs that appear to exist in practice, including the impact of energy oligopolies. In Sect. 3, we analyze the economic consequences of measures that aim to tackle the windfall profits that energy companies make, including auctioning. In Sect. 4, we not only sketch the pros, but also some cons of auctioning as an alternative to circumvent those additional profits. In Sect. 5 we draw conclusions.

\section{The impact of opportunity costs on energy prices}

Do energy companies make windfall profits from emissions trading? To answer this question we briefly indicate how emissions trading works and clearly define the term windfall profits. Under the Kyoto Protocol the EU is committed to achieving an $8 \%$ reduction in greenhouse gas emissions by 2008-2012 compared to emission levels in 1990. Emissions trading is an instrument to reach that target. In the EU system, the emissions are capped and polluters are allowed to trade emissions in the form of emission rights. At least until 2012, they primarily receive those rights, called allowances, for free. If participants decide to trade, the buyer is allowed to emit more, but the seller must emit less (e.g. Dales 1968). This scheme is both effective and efficient: the environmental target is met at lowest costs (e.g. Woerdman 2005).

However, the emissions trading scheme is not without problems. Energy companies are now accused of making windfall profits. These are the profits due to the introduction of the emissions trading scheme. Windfall profits arise because producers pass on the market value of the emission rights to consumers via a markup on energy prices, while the producers obtained those rights for free. Should energy consumers pay for the allowances that energy producers obtained for free? The answer is yes. The crucial reason being that emission rights obtained free of charge have "opportunity costs" (e.g. Grafton and Devlin 1996; Nentjes et al. 1995).

In economics, the concept of opportunity cost must be taken into account whenever a resource can be used in alternative ways (Varian 2003). In general, when you consume more of good 1, you may have to give up some consumption of good 2. If that is the case, giving up the opportunity to consume good 2 is the economic cost of more consumption of good 1. A more concrete example is the wage rate. The wage rate is not only the price of labour, it is also the opportunity cost of leisure. If your salary is $€ 20$ per hour, then an extra hour of leisure costs you $€ 20$ in forgone income.

A similar reasoning can be applied to emission rights. Instead of using the free allowances, the firm could have sold them at the current market price. When selling its output, for instance electricity, the firm wants to recover this opportunity forgone in the product price. An emissions trading scheme puts a price on residual emissions, which means that they are no longer for free. "Consuming" the right to emit when producing output is a cost to the firm. If producers are to be motivated 
not to sell those rights, then the proceeds of such a sale need to be compensated via the energy prices. In other words: although an energy producer does not have to pay for the emission rights, he does employ them to cover the emissions when producing output and therefore he must pass on the value of those rights in the product price. Below, we illustrate this with a numerical example.

\subsection{Numerical example}

Let us consider the example of energy producers. They are assumed to be pricetakers, which means that these producers take energy prices and allowance prices as given. Suppose that prior to the introduction of a system of tradable emission rights, at time $t=0$, the cost price of, say, a unit of electricity is $€ 65$, consisting of $€ 50$ fuel costs, $€ 10$ capital costs and $€ 5$ labour costs. The normal profit is $€ 5$. In equilibrium, the market price for a unit of electricity is then $€ 70$ (excluding indirect taxes and distribution costs). The left side of Fig. 1 illustrates that with the introduction of an emissions trading scheme, at time $t=1$, the market value of the free allowances is added to this price. (Note that the right side of Fig. 1 is not referred to here and will be used later on in this article). Suppose that the market value of an allowance implies a $€ 20$ mark-up on the electricity price (i.e. from the market price of an emission right per unit of $\mathrm{CO}_{2}$ producers derive a mark-up per unit of electricity). Including the normal profit, the electricity price becomes $€ 90$ per unit of electricity. The market value of the emission rights is then fully passed on to consumers. The

Situation at $\mathbf{t}=\mathbf{1}$

Electricity price $=€ 90$

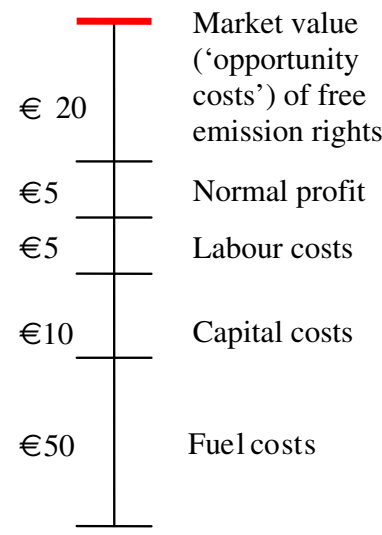

Costs

per unit of electricity
Situation at $\mathbf{t}=\mathbf{2}$

Electricity price $=€ 70$

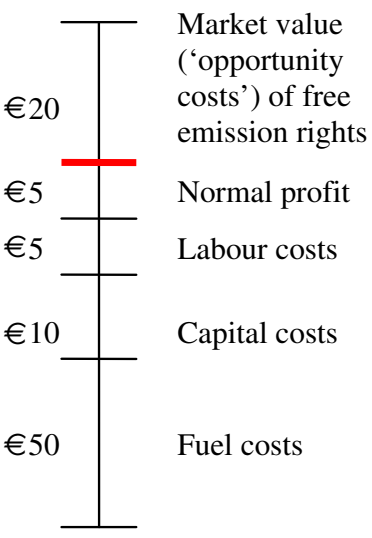

Costs

per unit of electricity

Fig. 1 Electricity price with and without 'opportunity costs' 
reason being that the producer could have sold those rights. He will not sell if and only if he can earn the revenue forgone via the electricity price.

In his published yearly accounts the producer will report a total profit per unit of electricity of $€ 25$ and, second, the normal profit of $€ 5$. This is clearly a situation in which reporting the results in the yearly accounts differs from economic reality: there is only an economic profit of $€ 5$, while $€ 20$ is necessary to compensate for the opportunity costs of using the rights.

\subsection{Popular misconceptions}

The cause of the windfall profits, that is grandfathering, is not always well understood in the climate change literature and popular press. The following quote taken from an interview with Kevin Smith, a researcher with Carbon Trade Watch, illustrates this: 'Governments massively over allocated emissions permits to the heaviest polluting industries in the initial round. This resulted in windfall profits for some of the biggest polluters who in exaggerating their need for emissions allowances, received enormous amounts of permits that they could then profitably sell on' (in: Cunningham 2007: 27-28). This is indeed a popular view, but it is not correct.

Windfall profits should not be confused with profits arising from "overallocation", meaning that companies get more (in this case free) allowances then they need, which they can sell for cash on the market (provided that there is still sufficient demand). Over-allocation arises solely from leniency in the setting of the emission target; windfall profits arise solely from the allocation method of grandfathering. With stringent targets, electricity producers will still realize windfall profits, because the grandfathered allowances entail opportunity costs for them. However, with a smaller number of free allowances, the price of those rights will be higher. Therefore, a more stringent emission cap does not necessarily reduce the size of the windfall profits, but might even increase those profits.

Although over-allocation should thus not be confused with windfall profits, they are intertwined in the sense that over-allocation in principle should lead to a low (or zero) carbon price, resulting in low (or no) windfall profits. This only occurred during 2007 after data on over-allocation had been published. Forward sales in 2007 of allowances, though, did not suffer from over-allocation (with prices ranging between about $€ 12$ and $€ 24)$, since those allowances are to be used in the more stringent 2008-2012 period (COM 2007).

Others question the opportunity costs reasoning all together and suspect that it is wrong to pass on the market price of free allowances to consumers in the first place. Jepma, for instance, writes: 'Because allowances are grandfathered, and most installations seem to succeed in passing on allowance prices onto end users without being charged accordingly, they eventually capture windfall profits. [...] [T]he group that eventually pays for the rent [...], is the group of final end users, or consumers, who eventually pay the bill for the net windfall gain' (Jepma 2006: 6-7). However, consumers should, as explained above, pay for the allowances that energy producers obtained for free, because the use of those allowance entails opportunity costs. 
Another misunderstanding is the idea that the emission reduction costs must be subtracted from the opportunity costs. Instead of using the free allowances, the energy producer could have sold them and should thus pass on their opportunity costs to consumers. But if he would actually sell them, he must first reduce his emissions, which comes at a cost. Some seem to believe that the emission reduction costs must be subtracted from the opportunity costs, but this is wrong. In the case that a producer does not reduce pollution in a grandfathering scheme, he faces opportunity costs of the allowances and no emission reduction costs. In the case that he does reduce pollution, he not only faces emission reduction costs, but he also brings in revenues from selling the allowances. The allowances set free through emission abatement can be seen as a side product of the firm. His profit is the difference between the revenues from selling the side product, namely allowances, and its production costs, that is the emission reduction costs. If the producer still produces some emissions after the abatement, he will have to cover these remaining emissions with allowances.

\subsection{Unsurprising surprise}

About 2 or 3 years before 2005, when emissions trading started, the Council of Ministers decided to use grandfathering in the EU in order to make carbon pricing acceptable for their industries and to protect their countries' competitiveness. Only 1 or 2 years after the start of this scheme, politicians were surprised that electricity companies made windfall profits. However, this should not have been a surprise at all. The grandfathering of emission rights generates additional cash for electricity producers, improving the financial position of shareholders. The value of a share increases, because the electricity company receives an asset with a market value for free.

What is surprising, though, is that politicians did not know, or maybe act as if they did not know, that this was going to happen. Already at the end of the 1990s, Bohm (1999: 21) wrote: 'Gratis allocation such as grandfathering [...] [implies] that these firms obtain windfall profits (as compared to not being given the permits gratis)'. More recently, Richard Douthwaite of the Foundation for the Economics of Sustainability (Feasta) stated in an interview that '(...) EU officials who planned the ETS [EU Emissions Trading Scheme] were aware of the windfall effect, but opposition from industry would have made it impossible to introduce the ETS if the permits had not been given away. [...] It was essentially a massive bribe' (in: Cundy 2007: 1). We are not sure as to what politicians did and did not foresee in advance, but we know for sure that the windfall effect was recognized in the economic literature several years before the start of emissions trading in the EU.

\section{Limits to passing through opportunity costs}

In practice, an interesting phenomenon occurs. Electricity producers should fully incorporate the opportunity costs of grandfathered allowances in their product prices, but they only do this to a limited extent. In The Netherlands, for instance, the 
rate of passing on the emission price in electricity prices is about $100 \%$ in the electricity spot market. However, for forward sales (e.g. sales made in 2005 to be delivered in 2006) there is evidence that this rate was only roughly $50 \%$ for peak prices and even less for off peak prices (Frontier Economics 2006).

Sijm et al. (2006) calculate that, with $80 \%$ certainty, pass-through rates vary between 60 and 117\% in Germany and between 64 and $81 \%$ in The Netherlands. They explain the high figure for Germany by pointing out that (relatively cheap) coal generators benefit from higher peak power prices in forward contracts, which result from (relatively expensive) gas generators setting the marginal power price during peak hours. Therefore, rising gas prices in 2005 may have led to a modest overestimation of the pass-through rate for (coal-generated) power in Germany. In general, they conclude that the pass-through rates in 2005 and 2006 are limited and vary between 60 and $100 \%$ in both countries. In a more recent report, Point Carbon (2008) concludes that, during the period 2005-2007, pass-through levels vary between 75 and 100\% in both Germany, the United Kingdom and Spain, between 0 and $75 \%$ in Italy, and between 45 and $65 \%$ in Poland.

Why do electricity producers only partly behave according to what is to be expected in theory? We distinghuish three groups of explanations for this:

- Oligopolistic nature of the electricity market

- Other market factors (e.g. concerning demand, supply and uncertainty)

- Institutional limitations (e.g. the impact of regulations).

\subsection{Oligopolistic markets}

Nearly all individual electricity markets, also in the EU, are to be characterized as oligopolistic (e.g. Gutiérrez-Alcaraz and Sheblé 2006). We want to make clear from the outset that an oligopolistic market structure does not invalidate the opportunity costs reasoning itself. The passing on of the opportunity costs of free allowances to consumers is not a consequence of too little competition on the energy market, but a consequence of the grandfathering design of the emissions trading market. In passing on those costs, electricity producers are not colluding, but behaving similar to firms operating on a perfectly competitive energy market.

However, the increase in the cost price of electricity by fully incorporating the opportunity costs of free allowances is only partly reflected in a higher market price for electricity. The reason for that phenomenon is, indeed, the oligopolistic structure of the electricity market (Sijm et al. 2005: 98-103). This is basic micro-economics. Any increase in costs (thus also the opportunity costs of free allowances) leads to higher marginal costs, causing the supply curve to shift upwards. First assume a perfectly competitive electricity market. When demand is inelastic, the aforementioned cost increase (say, $\Delta C$ ) leads to an electricity price increase (say, $\Delta P$ ) of the same magnitude. In symbols: $\Delta P=\Delta C$. However, when demand is elastic, the electricity price increase is smaller than the increase in costs, because demand decreases when the electricity price increases. In symbols: $\Delta P<\Delta C$. In such a competitive market the electricity price is given because no company can influence the market price: this price then equals marginal revenues. Now introduce the reality 
of an oligopolistic electricity market. In that case, the electricity price is no longer given because a limited number of companies has some impact on the market price, so that they face a downward sloping marginal revenue curve. Assuming a similar aggregate supply curve and elastic demand as in previous case, we again find that the same cost increase leads to a smaller increase in the electricity price. In symbols: $\Delta P^{*}<\Delta C$ (and $\Delta P^{*}<\Delta P$ ). In other words: the opportunity costs of free allowances are only partly reflected in a higher power price when the electricity market is oligopolistic. This has nothing to do with those opportunity costs; it has everything to do with the market structure.

A different question is whether large energy companies could manipulate the allowance market to make excessive profits. As an answer to this particular question, we must realize that the impact of such a company on the allowance price should not be exaggerated. The allowance market has a much larger number of participants than the electricity market: the EU emissions trading scheme covers about 10.500 installations in 27 Member States, while electricity producers account for more than half of total covered emissions (COM 2007; Christiansen et al. 2005). Convery and Redmond (2007) calculated (based on the Herfindahl-Hirschman Index) that the electricity-generating sector is not likely to be able to have market power in the emissions trading market. Nevertheless, it is not the entire number of yearly allowances that are freely available on the market. A very large part of these allowances are taken up in production and cannot be freed easily on short notice. To some extent, their price might thus be affected when a significant amount of allowances would become available. Ultimately, it is an empirical question whether a small number of producers can affect allowance prices to an extent that it becomes observable in electricity prices.

When there is allowance market power of one or more firms, their impact on the allowance price depends on whether they are buyers or sellers (Hahn 1984; Westskog 1996). It is in the interest of the seller(s) to keep the allowance price above the price that clears the market when there is perfect competition. If they succeed in increasing the market value of grandfathered permits, this higher allowance price will be passed through in the energy price. This means that all firms holding such grandfathered emission rights make higher windfall profits than they would have had under perfect competition. However, the higher price for energy will also lead to lower demand and thus reduce the profits of their operations in the energy market. The first-best solution in such a case of abuse of market power is of course intervention by the EU competition authority, i.e. the European Commission.

\subsection{Other market factors}

The report by Frontier Economics (2006: 22) mentions several other reasons for a limited carbon add-on. One of the reasons is that the forward sales of energy for 2005 took place 2 or 3 years earlier, when the emissions trading scheme was not yet operational. Electricity companies then had expectations of the $\mathrm{CO}_{2}$ price that may have differed from the market price that emerged when the scheme became operational. Another reason is that peak electricity prices are so much higher than the cost price, given their steep demand, that it becomes impossible to discern the 
$\mathrm{CO}_{2}$ mark-up in these peak prices. Furthermore, particular fuels can be used to produce electricity, such as biomass, which do not cause $\mathrm{CO}_{2}$ emissions and therefore do not need emission rights to cover them. Moreover, Sijm et al. (2005: 38-39) add that passing through the opportunity costs is more difficult in over-thecounter (OTC) markets where electricity is traded (not on relatively transparent power exchanges but) via bilateral, longer-term contracts.

Competition with companies within the EU but outside the emissions trading scheme also limits possibilities to pass on the opportunity costs of free allowances to consumers. In EU Member States with a lot of nuclear plants, like France, or in countries with many hydro installations, like Sweden, fossil fuel plants are not able to pass through their carbon costs (Sijm et al. 2005). Also international competition with companies in countries outside the EU emissions trading scheme poses limits to passing on the carbon mark-up to consumers. This is not relevant for the electricity sector, since almost no power is imported from outside the EU, but it is relevant in particular for the aluminium industry (Smale et al. 2006).

Competitors outside the EU and outside the emission trading system need not include the opportunity costs in their prices. Companies within the EU will then not be able to pass on the opportunity costs. Their alternative is to stop producing and sell the allowances. However, if the costs of stopping (namely the loss of value associated with the liquidation of the plant vs. the value when continued in production) exceed the benefits of selling their allowances, then these producers will continue production as if these allowance do not carry an opportunity cost. It is indeed unlikely that producers will actually leave the market, not only because the potential value loss associated with scrapping plants is high, but also because most EU Member States have determined that a producer looses its allocated allowances when shutting down an installation. Only The Netherlands and Sweden allowed closed facilities to retain allowances until the end of the trading period (Ellerman and Buchner 2007: 76).

When energy-intensive industries in the EU would actually relocate to countries without an emission cap, this would be referred to as "carbon leakage". Emissions outside the EU would then increase as a direct result of the policy to cap emissions in the EU. However, based on trade data from 1999 to 2006 in a case study of the above-mentioned aluminium industry, Reinaud (2008) concludes that carbon leakage did not yet occur. But she also notes that this may (or may not) change in a few years time, for instance when long-term electricity contracts expire, making continued research of this issue desirable.

\subsection{Institutional limitations}

Neuhoff et al. (2006) argue that power producers expect their current emissions to be used for the allocation of allowances in a next commitment period. According to Sijm et al. (2006: 52), this gives producers an incentive to increase output now and voluntarily restrict the pass-on of the full allowance price to their energy bids. Moreover, these authors add, among other things, that the regulatory threat of governments to intervene when energy producers make excessive windfall profits might induce companies to limit the carbon mark-up. Finally, several authors point 
to the fact that electricity prices in a few countries, such as France, Spain and Ireland, are subject to regulation which simply prevents operators to pass on the opportunity costs to the wholesale market (e.g. Matthes et al. 2005: 10; Sijm et al. 2005: 41; Grubb and Neuhoff 2006: 15).

In spite of all this, Grubb and Neuhoff conclude after considering a number of theoretical and empirical studies: 'The power sector can and does pass through the bulk of marginal/opportunity $\mathrm{CO}_{2}$-related costs to the wholesale power markets, as expected in a competitive system [...]' (Grubb and Neuhoff 2006: 11). Also the European Commission asserts: 'In some sectors the degree of outside competition [...] has limited pass through of the value of allowances. In other sectors, notably power generation, pass through potential has been more important [...]' (COM 2006a: 4).

\section{Options to tackle the windfall profits}

The next question is what politicians can do about the windfall profits of the participants, in particular the electricity producers, in the EU emissions trading scheme. Below we first analyze the option of forbidding those companies to pass on the opportunity costs of grandfathered allowances to consumers. We then consider the options of taxing the windfall profits, strengthening the emission caps and auctioning the allowances.

\subsection{Forbidding the mark-up}

Suppose politicians want to tackle the windfall profits problem by making the markup impossible for the electricity producer on the right side of Fig. 1. This would mean that the market value (of €20) of the emission rights that have been allocated free of charge is not allowed to show up in the electricity price anymore. The result is that the market price is pushed back (from $€ 90$ at time $t=1$ ) to $€ 70$ at time $t=2$, the same price level as before the introduction of emissions trading (at time $t=0$ ). What would the producer do? The producer would then sell both his power station and his emission rights. By selling the power station he recovers his initial investment (less depreciation), which he can invest in assets with a similar risk and profit profile as he had with the power station, and for the emission rights he receives $€ 20$ per unit of energy on his bank account. The producer is then better-off (namely $€ 20$ per unit of energy) than if he would have continued producing electricity.

The consequence of this maximum price policy would be that producers exit the market. Such an exodus would lower the supply of energy. Without price regulation, the market price would rise as a result of this shortage of supply, to the level where the electricity price would be $€ 90$ again. However, the price regulation makes this market correction impossible. The exodus would also lead to an additional supply of emission rights, lowering their prices. It would even lower the market value of power stations due to the additional supply. No party will be interested to buy power stations when the energy price is $€ 70$. Therefore, the ultimate consequence of 
prohibiting producers from passing on the opportunity costs of allowances is that such a measure endangers "security of supply", which would thus violate one of Europe's core principles of a common energy policy (COM 2006b: 4) and possibly infringe upon Directive 2005/89/EC on security of electricity supply.

Whether electricity companies will indeed exit the market when the energy price is forced below the level of their variable costs depends on their expectations. Those firms might continue production if they expect a more profitable pricing policy in the foreseeable future in which passing on the opportunity costs of emission rights is in fact allowed (for instance a possible regime, after 2012, in which all the emission rights are auctioned off). A producer then accepts a loss now, because he wants to retain his position on a market where he expects to make profits again in the future.

The closure provisions in most (though not all) EU Member States further reduce the incentive to leave the market. When a producer closes an installation, he looses his allowances and he will not receive $€ 20$ per unit of energy because he has no allowances to sell. The implication is that shutting down becomes more expensive. Those closure rules are inefficient, because they discourage the termination of old and inefficient plants (e.g. Egenhofer and Fujiwara 2005). Interrupting the allowance allocation after a plant shuts down can thus be seen as an indirect subsidy to production. The European Commission even proposed that all closed installations from 2013 onwards shall no longer receive any allowances for free (COM 2008: 9).

\subsection{Taxing the profits}

Some politicians considered to tax the electricity producers for the windfall profits they made (e.g. a few Social Democrats in Germany and the United Kingdom). A "windfall tax" would not prevent windfall profits from being made ex ante, but it would tax them ex post, which-presumably_would end those profits.

However, such a tax is a problem for three reasons. First, the tax administration cannot directly find the opportunity costs on the electricity bills of consumers or in the bookkeepings of electricity producers. Rather, the opportunity costs are indirectly implied in the profit and loss statements of producers. Second, a windfall tax is not easy to define. It implies that the "normal" level of profit for an electricity producer is objectively measurable. Anything above that level is then a windfall profit that should be taxed. This would provide producers with an incentive to hide such profits as costs in their yearly accounts, or to adjust asset values in order to step up the investment charges in calculating the normal profit. Addressing such behaviour requires additional, complex regulation with the risk of seriously inhibiting efficiency. Third, should the tax indeed be successful in transferring the firms' opportunity costs to the government, then the impact is similar to forbidding a full mark-up, which would endanger security of supply. Taxing the windfall is obviously not the same as forbidding the mark-up, but it does have the same effect. Because the mark-up on the electricity price will be taxed away immediately by the government, electricity producers would receive no compensation for the opportunity costs of their allowances. A producer is then better-off when he sells the allowances and leaves the energy market. 
Apart from a potential legal incompatibility with Article 10 of Directive 2003/87/ EC which states that emissions shall primarily be allocated free of charge until 2012, the windfall tax soon turned out to be politically unacceptable, because it would basically force polluters to pay for their allowances. The fact that the industry accepted the emissions trading scheme in the first place was, of course, because they did not have to buy their emission rights (as predicted by Baumol and Oates (1988), for instance).

\subsection{Strengthening the caps}

Various politicians then proposed to give the electricity companies between 2008 and 2012 a relatively stringent emission target compared to the other sectors in the system (e.g. the governments of The Netherlands, Germany, Belgium and the United Kingdom). A year after the scheme had become operational, it turned out that overall $\mathrm{CO}_{2}$ emissions were about 80 million tonnes or $4 \%$ lower than the number of allowances distributed to installations for 2005. Ellerman and Buchner (2006: 33) provide two basic explanations for this. First, the emission caps were not stringent enough, partly because the caps were based on emission estimates and partly due to lobbying efforts of energy-intensive industries. Second, market observers had not only overestimated the level of $\mathrm{CO}_{2}$ emissions, but they might also have underestimated the amount of abatement that would occur. A third, additional explanation might be that the industry has emitted less than it was allowed to, creating a perception of over-allocation, because firms wanted to bank emissions for, say, 2007 on the assumption that by then economic growth and hence energy use would have increased.

A proposal to "under-allocate" electricity companies between 2008 and 2012 by giving them a relatively stringent emission target will not solve the problem of windfall profits. A more stringent emission ceiling would lead to a lower supply of emission rights (in comparison with demand) and, hence, to a higher price of those rights. This would not only cause the electricity price to rise, but it could also mean that the absolute level of windfall profits increases instead of decreases: less emission rights would be handed out, but they would have a higher value.

To get around this problem of "less rights with higher values" when allocating less emission rights to the electricity sector, some EU Member States, such as The Netherlands, have decided to redistribute (part of) those rights to the other participants in the scheme. The Dutch government, for instance, decided to allocate $15 \%$ less rights over the period 2008-2012 to the electricity sector. It will give onethird of those unallocated rights to non-electricity participants and it will sell twothirds on the market. The proceeds of the sale will go to the energy consumers. Although this redistribution policy does not lead to a higher allowance price, ceteris paribus, it does imply that the windfall profits will only slightly decrease with about $10 \%$ (namely two-thirds of $15 \%$ ). One-third of the windfall profit will shift to the non-electricity sectors. Therefore, windfall profits will not disappear at all, which should be no surprise if one recognizes that grandfathering is the cause of the windfall profits, not over-allocation. 


\subsection{Auctioning the allowances}

The discussion above demonstrates that plans to end the windfall profits prior to 2012 are all doomed to fail. For the period after 2012, governments have the option to auction off the allowances. This was proposed by the European Commission (COM 2008). The European Council agreed, but also allowed transitional free allocation for existing electricity generators primarily in Eastern Europe, so that full auctioning in the power sector will be applied everywhere in the EU only after 2020 (EC 2008). When each electricity producer has to buy emission rights to cover his $\mathrm{CO}_{2}$ emissions, this implies additional out-of-pocket costs. The producers will then adjust their product prices to reflect these extra costs. Furthermore, producers will not report windfall profits anymore in their yearly accounts. The costs of purchasing emission rights which producers incorporate in their product prices under auctioning are easier to accept for consumers than the argument that the opportunity costs of free rights are to be passed on to them under grandfathering. Auctioning is then consistent with an "extended" interpretation of the polluter-pays principle which includes both efficiency and fairness, because polluting firms need to buy the emission rights instead of enriching their shareholders (Woerdman et al. 2008). By auctioning the allowances, the capital gift will shift from the shareholders of energy companies to the government. Consequently, in its post-2012 proposal, the European Commission correctly stated that 'auctioning (...) should also eliminate windfall profits' (COM 2008: 14).

\section{Auctioning as a first-best solution?}

The upshot of the discussion above is that auctioning is the first-best solution from an economic perspective: it eliminates windfall profits, prices the marginal $\mathrm{CO}_{2}$ unit and provides incentives to innovate (e.g. Cramton and Kerr 1998). Some authors also expect that auctioning will provide a clearer long-term price signal (Hepburn et al. 2006). Until 2012, only $10 \%$ of the emissions rights is allowed to be auctioned off: at least $90 \%$ has to be allocated for free, according to Article 10 of the EU Directive on emissions trading. After 2012, the auctioning rate for the electricity sector will be $100 \%$, but transitional free allocation is possible for existing power plants in Member States with a poor interconnectivity of their electricity grid or in relatively poor Member States where more than $30 \%$ of the electricity is produced with a single fossil fuel (such as coal; EC 2008: 14). However, in those particular Member States the auctioning rate must be at least $30 \%$ in 2013 and will be progressively raised to $100 \%$ no later than 2020 . This means that after 2020 , the auctioning rate for the power industry will be $100 \%$ everywhere in the EU.

As opposed to emissions trading based on auctioning, some economists argue in favour of a carbon tax which would also imply that energy producers stop making windfall profits (e.g. Shapiro 2007; Jepma 2006). Additional advantages are carbon price certainty and avoidance of lobbying on the allocation of allowances, its advocators claim. However, the biggest problem of the early climate policy tools in the 1990s was that they were unable to prevent carbon emissions from rising 
(Woerdman 2004). A carbon tax suffers from a similar problem: it is less environmentally effective than a cap-and-trade scheme. The substitute for a common cap-and-trade scheme in the EU is a uniform carbon tax. Because information is incomplete, the European Commission becomes involved in a trialand-error process of (re)adjusting the tax rate trying to reach the EU emission target. Moreover, economic growth tends to increase the consumption of fossil fuels and thus requires steady upward adjustments of the carbon tax. Lobbying and resistance from the industry is to be expected every time that the tax increase is necessary to attain the emission target.

Auctioning will put an end to the windfall profits, but unfortunately it also has its drawbacks. Apart from the difficulties of auction design, auctioning could spark a "secondary allocation debate" by shifting the allocation problem to the issue of how to recycle the auction revenues (Egenhofer and Fujiwara 2005: 26). Should the revenues be redistributed to the power producers as a compensation for the costs they have to make to comply with the new regulation, should the revenues go to consumers as a compensation for their higher energy bill, or should it flow into the treasury of the state? And in the latter case, should the additional state revenues be used to finance climate-friendly technologies, to lower taxes on labour, or to support other (non-environmental but) socially desirable projects?

Interestingly, in a survey of 151 firms in the United Kingdom, $75 \%$ of them wants to see the funds raised by environmental taxation or regulation to be spent on green initiatives (Manning and Howlett 2007: 15). The other option of letting the auction revenues flow back to the industry by lowering labour taxes is generally preferred by economists and would imply a cost shift: pollution costs more, labour costs less (Goulder 1995).

This issue of what to do with the auction revenues should not be dismissed lightly. The comparable problem of what to do with the revenues from a carbon tax even partly explains why such a tax was eventually rejected. Jos Delbeke, DG environment at the European Commission and designer of a carbon tax proposal in the 1990s, said in an interview: 'The level of the tax was quite significant. And that was part of the problem. [...] It's very difficult to discuss a tax measure. It's even more difficult to agree on what to do with the revenues' (in: Jones 2007: 2). Nevertheless, the EU accepted more auctioning of allowances after 2012, not only because windfall profits caused so much political turmoil, but also because emissions trading was legally embedded, institutionally "locked-in", in all Member States and their companies, making a shift in the allocation regime a relatively small step.

The European Commission proposed to use at least $20 \%$ of the auction revenues for environmental purposes, such as renewable energies, carbon capture and storage, and avoidance of deforestation in developing countries (COM 2008: 23). The European Parliament wanted to earmark at least $50 \%$ of those revenues for climate measures in developing countries (EP 2008: 15). The European Council decided that Member States can determine the use of auction revenues themselves and takes note of their willingness to use at least $50 \%$ of those revenues for actions to reduce greenhouse gas emissions, partly in developing countries (EC 2008: 7). The European Council thus shifted the "secondary allocation debate" to Member State level. 
Another problem of auctioning off the allowances is that it will deteriorate the net cash flow of EU companies facing outside-system competition, like the aluminium industry. As argued above, these companies will not be able to pass on the costs of these allowances to their buyers. Their net cash flow will decrease with an amount equal to the amount paid for the auctioned allowances. Firms with the prospect of negative long-run profitability of their operations, which might hold out for a while when allowances are grandfathered, have a stronger incentive to stop immediately when allowances are auctioned due to liquidity and solvency problems. The European Council therefore decided to allow $100 \%$ free allocation of allowances for (sub)sectors exposed to international competition and thus to a significant risk of carbon leakage (EC 2008: 2).

Auctioning also raises an intriguing fairness trade-off. Auctioning is more acceptable than grandfathering to energy consumers, because it removes the windfall profits. However, grandfathering is more acceptable than auctioning to energy producers, because they receive an asset with a market value for free (e.g. Harrison et al. 2007). In the 1990s, the electricity producers opposed the proposal of a carbon tax, but they accepted the idea of an emissions trading scheme, precisely because they did not have to pay for their emissions via grandfathering. One might argue that changing the "rules of the game" by introducing auctioning is not entirely fair to its main players: the energy companies. They are now basically "locked" into the system and may perceive such a step as a form of opportunistic behaviour by the government. Moreover, we have seen that producers do not fully incorporate the opportunity costs in their electricity prices. With auctioning it is improbable that such a limited pass-on can continue. Therefore, consumers might actually be better off under grandfathering than under auctioning.

Auctioning may be the first-best solution in terms of ending windfall profits, one particular aspect of the emissions trading scheme, but it is a second-best solution in terms of political acceptability for the emissions trading scheme as a whole. The first aspect explains the choice for more auctioning after 2012, but the second aspect explains its gradual introduction and the exemptions created for particular industries and Member States.

\section{Conclusion}

Theoretically, the instrument of emissions trading is not only effective as a result of the emission caps, but it is also efficient. Each unit of carbon has a price: either the price of purchasing emission rights or the opportunity costs of using the rights. In addition, emissions trading gives an incentive to innovate, since costly emission reduction technology now also generates revenues by selling the emission rights that become available. This makes it more attractive to invest in cleaner technologies.

However, the emissions trading scheme in the EU suffers from overindulgent emission caps and windfall profits made by energy companies. Our analysis revealed that windfall profits resulting from grandfathering is not the same as an overallocation resulting from lenient emission caps. Energy companies would also make windfall profits in case of stringent caps by incorporating the (higher) market value of 
(less) grandfathered allowances in the energy price. Moreover, we emphasize that grandfathering entails costs for firms, namely the opportunity costs of the emission rights when they are used for covering the emissions. Instead of using the allowances, the firm could have sold those emission rights. These costs are part of the cost price and thus have to be incorporated in the energy price. An energy producer will not sell his allowances only if he can earn the revenue forgone via the electricity price.

Energy consumers consider the carbon mark-up to be more acceptable when energy producers directly had to purchase the allowances at an auction. The costs of purchasing emission rights which producers incorporate in their product prices under auctioning are easier to accept for consumers than the argument that the opportunity costs of free rights are to be passed on to them under grandfathering. Because auctioning is allowed to a very limited extent until 2012, shareholders can enjoy the financial benefits of grandfathering at least for a few more years to come.

Emissions trading based on either auctioning or grandfathering is an efficient instrument to reach the emission target. Windfall profits arise under grandfathering because energy companies receive a capital gift, making their shareholders richer. This is not a surprise, but it is a fact that was known in the literature years before the start of the scheme. In that sense, windfall profits are a political problem, not an economic problem. A few years ago, grandfathering was the political solution to make the pricing of carbon acceptable to energy producers. Today, grandfathering is seen as a political problem, because energy consumers find the windfall profits of the producers unfair. Politicians face the dilemma that auctioning may strengthen fairness for consumers, but undermines fairness for producers. Nevertheless, this difficult equity trade-off does not undermine the efficiency of the scheme at large.

The EU decided to auction off allowances to electricity producers after 2012, but also created exemptions allowing transitional free allocation primarily in Eastern European Member States until 2020. This not only means that the debate on windfall profits will come to an end, but also that the controversy will remain for more than a decade to come. The political turmoil is not over yet.

Acknowledgment We thank Catrinus Jepma for discussing the issue of windfall profits extensively with us. We also appreciate the comments on an earlier version of this article by the participants and organizers, in particular Jürgen Backhaus and Frank Stephen, of the 20th Workshop in Law and Economics held in 2007 in Erfurt, Germany. The article also benefited from the remarks made by the participants and organizers, in particular Ann-Sophie van den Berghe, of a Seminar on Law and Economics held in 2007 at the Utrecht School of Economics, The Netherlands. We could further improve the article based on some ideas we received from the participants, in particular Stefano Clò, of the 24th Annual Conference of the European Association of Law and Economics held in 2007 in Copenhagen, Denmark. Finally, we thank the reviewers of the journal for their comments. Any remaining errors are our own.

Open Access This article is distributed under the terms of the Creative Commons Attribution Noncommercial License which permits any noncommercial use, distribution, and reproduction in any medium, provided the original author(s) and source are credited.

\section{References}

Baumol, W. J., \& Oates, W. E. (1988). The theory of environmental policy (2nd ed.). Cambridge: Cambridge University Press. 
Bohm, P. (1999). International greenhouse gas emission trading-with special reference to the Kyoto protocol. TemaNord, 1999, 506. Stockholm: Department of Economics.

Böhringer, C., Hoffmann, T., Lange, A., Löschel, A., \& Moslener, U. (2005). Assessing emission regulation in Europe: An interactive simulation approach. Energy Journal, 26(4), 1-21.

Bonacina, M., \& Gullì, F. (2007). Electricity pricing under "carbon emissions trading": A dominant firm with competitive fringe model. Energy Policy, 35, 4200-4220. doi:10.1016/j.enpol.2007.02.016.

Christiansen, A. C., Arvanitakis, A., Tangen, K., \& Hasselknippe, H. (2005). Price determinants in the EU emissions trading scheme. Climate Policy, 5(1), 15-30.

COM. (2006a). Building a global carbon market-report pursuant to article 30 of Directive 2003/87/EC, $\operatorname{COM}(2006) 676$ final, 13 November 2006, Brussels: European Commission.

COM. (2006b). A European strategy for sustainable, competitive and secure energy, green paper, COM(2006)105 final, 8 March 2006, Brussels: European Commission.

COM. (2007). EU action against climate change: EU emissions trading-an open system promoting global innovation. Brussels: European Commission.

COM. (2008). Proposal for a directive of the European parliament and of the council amending directive 2003/87/EC so as to improve and extend the greenhouse gas emission allowance trading system of the community, 2008/0013 (COD), 23 January 2008, Brussels: European Commission.

Convery, F. J., \& Redmond, L. (2007). Market and price developments in the European union emissions trading scheme. Review of Environmental Economics and Policy, 1(1), 88-111. doi:10.1093/reep/ rem010.

Cramton, P., \& Kerr, S. (1998). Tradable carbon permit auctions: How and why to auction not grandfather, Discussion Paper 98-34, Washington DC: Resources for the Future (RFF).

Cundy, C. (2007). Trading our way into trouble? Environmental Finance, Reporting, March 2007.

Cunningham, J. (2007). Carbon jackpot. Professional Engineering, 7(March), 27-28.

Dales, J. H. (1968). Pollution, property and prices: An essay in policy-making and economics. Toronto: Toronto University Press.

EC. (2008). Energy and climate change-elements of the final compromise. Document, 17215(08), 12. Brussels: European Council EC.

Egenhofer, C., \& Fujiwara, N. (2005). Reviewing the EU emissions trading scheme: Priorities for shortterm implementation of the second round of allocation (Part I). Centre for European Policy Studies (CEPS): Brussels.

Ellerman, D., \& Buchner, B. (2006). Over-allocation or abatement? A preliminary analysis of the EU ETS based on the 2005 emissions data, Nota di Lavoro 139.2006, Milan: Fondazione Eni Enrico Mattei (FEEM).

Ellerman, A. D., \& Buchner, B. K. (2007). The European union emissions trading scheme: Origins, allocation, and early results. Review of Environmental Economics and Policy, 1(1), 66-87. doi: 10.1093/reep/rem003.

EP. (2008). Draft report on the proposal for a directive of the European parliament and of the council amending directive 2003/87/EC etc., Document 2008/0013(COD), 11 June 2008, Brussels: European Parliament (EP).

Frontier Economics. (2006). CO2 trading and its influence on electricity markets, final report for DTe, London: Frontier Economics Ltd.

Goulder, L. H. (1995). Environmental taxation and the "Double Dividend": A reader's guide. International Tax and Public Finance, 2(2), 157-183. doi:10.1007/BF00877495.

Grafton, R. Q., \& en Devlin, R. A. (1996). Paying for pollution: Permits and charges. The Scandinavian Journal of Economics, 98(2), 275-288. doi:10.2307/3440859.

Grubb, M., \& Neuhoff, K. (2006). Allocation and competitiveness in the EU emissions trading scheme: Policy overview. Climate Policy, 6, 7-30.

Gutiérrez-Alcaraz, G., \& Sheblé, G. B. (2006). Electricity market dynamics: Oligopolistic competition. Electric Power Systems Research, 76(9-10), 695-700. doi:10.1016/j.epsr.2005.09.012.

Hahn, R. W. (1984). Market power and transferable property rights. The Quarterly Journal of Economics, 99(4), 753-765. doi:10.2307/1883124.

Harrison, D., Klevnas, P., Radov, D., \& Foss, A. (2007). Complexities of allocation choices in a greenhouse gas emissions trading program. International Emissions Trading Association (IETA), Boston: NERA Economic Consulting.

Hepburn, C., Grubb, M., Neuhoff, K., Matthes, F., \& Tse, M. (2006). Auctioning of EU ETS phase II allowances: How and why? Climate Policy, 6, 137-160. 
Jepma, C. (2006, August). Some EU ETS 'tags. (Electronic) Joint Implementation Quarterly: Magazine on the Kyoto Mechanisms, August, 2006, 1-7.

Jones, C. (2007). Grasping for air. International Tax Review, May 2007, pp. 1-8.

Manning, J., \& Howlett, N. (2007). Saving the planet-can tax and regulation help? July 2007, PricewaterhouseCoopers.

Matthes, F., Graichen, V., \& Repenning, J. (2005). The environmental effectiveness and economic efficiency of the European union emissions trading scheme: Structural aspects of allocation (A Report to $W W F)$. Berlin: Öko-Institut.

Nentjes, A., Koutstaal, P., \& Klaassen, G. (1995). Tradeable carbon permits: Feasibility, experiences, bottlenecks, Dutch national research programme on global air pollution and climate change (NRP), NRP Report no. 410100 114, Groningen/Bilthoven: RuG/NRP.

Neuhoff, K., Martinez, K. K., \& Sato, M. (2006). Allocation, incentives and distortions: The impact of EU ETS emissions allowance allocations to the electricity sector. Climate Policy, 6, 73-91.

Point Carbon. (2008). EU ETS phase II-the potential and scale of windfall profits in the power sector, a report for WWF by point carbon advisory services, March 2008. Oslo: Point Carbon.

Reinaud, J. (2008). Climate policy and carbon leakage: Impacts of the European emissions trading scheme on aluminium. International Energy Agency (IEA): Paris.

Shapiro, R. J. (2007). Addressing the risks of climate change: The environmental effectiveness and economic efficiency of emissions caps and tradable permits, compared to carbon taxes, February 2007. Washington DC: Sonecon.

Sijm, J. P. M., Bakker, S. J. A., Chen, Y., Harmsen, H. W., \& Lise, W. (2005). CO2 price dynamics: The implications of EU emissions trading for the price of electricity, ECN-C-05-081, September 2005. Energieonderzoek Centrum Nederland (ECN): Petten.

Sijm, J., Neuhoff, K., \& Chen, Y. (2006). $\mathrm{CO}_{2}$ Cost pass-through and windfall profits in the power sector. Climate Policy, 6, 49-72.

Smale, R., Hartley, M., Hepburn, C., Ward, J., \& Grubb, M. (2006). The impact of $\mathrm{CO}_{2}$ emissions trading on firm profits and market prices. Climate Policy, 6, 31-48.

Varian, H. R. (2003). Intermediate microeconomics: A modern approach (6th ed.). New York: W.W. Norton \& Company. Inc.

Westskog, H. (1996). Market power in a system of tradeable $\mathrm{CO}_{2}$-quotas. The Energy Journal, 17(3), 85-103.

Whitehead, P. (2005). Who pays the price for carbon abatement? Energy Economics, 288, 10-14.

Woerdman, E. (2004). The institutional economics of market-based climate policy. Amsterdam: Elsevier.

Woerdman, E. (2005). Tradable emission rights. In J. G. Backhaus (Ed.), Elgar companion to law and economics (pp. 364-380). Cheltenham: Edward Elgar.

Woerdman, E., Arcuri, A., \& Clò, S. (2008). Emissions trading and the polluter-pays principle: Do polluters pay under grandfathering? Review of Law and Economics, 4(2), 565-590. 